\title{
TITLE:
}

\section{Influence of Ni-Oxide Anode Thickness on Performance Stability in Internal Reforming of Methane for Solid Oxide Fuel Cells}

\section{AUTHOR(S):}

Lee, Yi-Hsuan; Sumi, Hirofumi; Muroyama, Hiroki; Matsui, Toshiaki; Eguchi, Koichi

\section{CITATION:}

Lee, Yi-Hsuan ... [et al]. Influence of Ni-Oxide Anode Thickness on Performance Stability in Internal Reforming of Methane for Solid Oxide Fuel Cells. Journal of The Electrochemical Society 2013, 160 (6): F579-F584

\section{ISSUE DATE:}

2013-03-26

\section{URL:}

http://hdl.handle.net/2433/193703

\section{RIGHT:}

(C) The Electrochemical Society, Inc. 2013. All rights reserved. Except as provided under U.S. copyright law, this work may not be reproduced, resold, distributed, or modified without the express permission of The Electrochemical Society (ECS). 


\title{
Influence of Ni-Oxide Anode Thickness on Performance Stability
in Internal Reforming of Methane for Solid Oxide Fuel Cells
}

(E) Yi-Hsuan Lee, Hirofumi Sumi, ${ }^{*, a}$ Hiroki Muroyama, ${ }^{*}$ Toshiaki Matsui," and Koichi Eguchi;,z

Department of Energy and Hydrocarbon Chemistry, Graduate School of Engineering, Kyoto University, Nishikyo-ku, Kyoto 615-8510, Japan

\begin{abstract}
Influence of the materials and cell configuration, especially anode thickness, on the performance stability was examined during long-term operation of solid oxide fuel cells (SOFCs) with humidified methane $(\mathrm{S} / \mathrm{C}=0.1)$ at $1000^{\circ} \mathrm{C}$. Two kinds of anode materials were evaluated; i.e., $\mathrm{Ni}$-yttria-stabilized zirconia (Ni-YSZ) and Ni-samaria-doped ceria (Ni-SDC). The thickness of anode was controlled to be ca. 10,20, and $30 \mu \mathrm{m}$ in this study. Deterioration in performance was observed during a constant current operation with $10 \mu \mathrm{m}$-thick Ni-YSZ anode. On the other hand, the cell performance with 20 and $30 \mu \mathrm{m}$-thick Ni-YSZ was stable for $20 \mathrm{~h}$. These differences in performance stability were significantly related to the anode thickness. In addition, the same experiments were conducted for the cells employing Ni-SDC anodes. The cell performance was improved obviously during discharge for $20 \mathrm{~h}$ regardless of anode thickness. The improvement upon discharge is ascribable to an increase in catalytic activity of Ni-SDC and electronic conductivity of SDC, which is induced by the partial reduction of $\mathrm{Ce}^{4+}$ to $\mathrm{Ce}^{3+}$ under reducing atmospheres. Microstructural observation and Raman spectroscopy were also conducted for the anodes. The electrochemical behavior observed in each anode had a strong correlation with crystallinity of carbon deposited and deposition area.

(C) 2013 The Electrochemical Society. [DOI: 10.1149/2.075306jes] All rights reserved.
\end{abstract}

Manuscript submitted November 14, 2012; revised manuscript received March 15, 2013. Published March 26, 2013. This was Paper 793 presented at the Montreal, QC, Canada, Meeting of the Society, May 1-6, 2011.

Solid oxide fuel cells (SOFCs) are one of the promising power generation devices due to their high energy conversion efficiency and low emissions. High fuel flexibility of SOFCs has also attracted much attention for a simplified system; hydrocarbons such as methane and propane are directly introduced as fuels into SOFCs without external reforming processes. In this system, the conventional Ni-yttriastabilized zirconia (Ni-YSZ) cermet serves as a reforming catalyst of hydrocarbons as well as a fuel electrode. In the internal reforming operation, the performance deterioration induced by carbon deposition over the Ni catalyst is well-known as a serious problem. ${ }^{1-5}$ Although the supply of a large amount of steam with hydrocarbon suppresses the carbon deposition, the concomitant increase in the oxygen partial pressure at the anode results in the reduction of open circuit voltage (OCV) and the energy conversion efficiency. High content of steam in a fuel also gives rise to the change in the surface of Ni particles and the decrease in triple phase boundary (TPB) length, leading to the performance deterioration. ${ }^{6}$ Thus, it is desired to accomplish stable power generation by feeding a fuel with low steam to carbon $(\mathrm{S} / \mathrm{C})$ ratio; the carbon deposition boundary is theoretically located in the $\mathrm{S} / \mathrm{C}$ ratio of 1.0 in the temperature range of $900-1200^{\circ} \mathrm{C}^{7}$

Many studies have been devoted to achieve this target upon the internal reforming operation. Abudula et al. studied the effect of anode thickness on cell performance with Ni-YSZ cermets at $1000^{\circ} \mathrm{C}$ by supplying dry methane. ${ }^{8}$ The performance was improved with an increase in the anode thickness up to $70 \mu \mathrm{m}$. Eguchi et al. also reported that the internal reforming reaction of methane was insufficient for the $\mathrm{Ni}-\mathrm{YSZ}$ anode with ca. $100 \mu \mathrm{m}$-thick. ${ }^{9}$ Thus, the cell configuration such as an anode thickness is one of the key factors to determine the performance. The operating condition also affects the stability. Lin et al. have demonstrated the stable power generation at $800^{\circ} \mathrm{C}$ with passing a high current of $1.8 \mathrm{~A} \mathrm{~cm}^{-2}$ even in $3 \% \mathrm{H}_{2} \mathrm{O}-97 \% \mathrm{CH}_{4} \cdot{ }^{10}$ They concluded that the steam generated via the electrochemical reaction removed deposited carbon effectively, resulting in the suppression of carbon deposition. The application of other constituent materials is an alternative approach to avoid the carbon deposition. It has been reported that ceria serves as a promoter with $\mathrm{Ni}$ catalyst for hydrocarbon gas conversion. ${ }^{11,12}$ Furthermore, carbon deposition scarcely occurred over the ceria-supported catalysts. Thus, it can be expected that $\mathrm{Ni}$-ceria-based cermet is the promising anode for direct feeding

${ }^{*}$ Electrochemical Society Active Member.

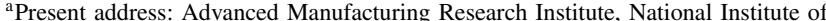
Advanced Industrial Science and Technology, Moriyama-ku, Nagoya 463-8560, Japan

${ }^{\text {z} E-m a i l: ~ e g u c h i @ s c l . k y o t o-u . a c . j p ~}$ of hydrocarbon fuels. Actually, some researchers have focused on the ceria materials for the internal reforming operation of SOFCs. Putna et al. studied the effect of samaria-doped ceria (SDC) on cell performance by supplying $20 \% \mathrm{CH}_{4}-80 \% \mathrm{~N}_{2}$ at $800^{\circ} \mathrm{C}$. An increase of SDC amount in the anode significantly improved the cell performance. ${ }^{13}$ Lee et al. showed that no obvious performance degradation with the $\mathrm{Ni}$-gadolinia-doped ceria anode in liquid hydrocarbon as fuel at $550^{\circ} \mathrm{C}$ for $500 \mathrm{~h} .{ }^{14}$ In our previous study, the influence of oxide species in the cermet on the carbon deposition behavior has been investigated at $1000^{\circ} \mathrm{C}$ under open-circuit and discharged states. ${ }^{1}$ The cell with $\mathrm{Ni}-$ SDC anode was stably generated in a short period, less than $6 \mathrm{~h}$, during the galvanostatic operation with $0.3 \mathrm{~A} \mathrm{~cm}^{-2}$ by feeding the humidified propane with $\mathrm{S} / \mathrm{C}$ of 0.8 , whereas the terminal voltage for $\mathrm{Ni}-\mathrm{YSZ}$ anode was degraded by ca. $30 \%$. Note that, however, the amount of deposited carbon over Ni-SDC cermet was larger than that over $\mathrm{Ni}-$ YSZ under the open-circuit state. Such a peculiar behavior observed in Ni-SDC will be related to the partial pressure of oxygen $\left(P\left(\mathrm{O}_{2}\right)\right)$ in the exposed atmosphere. The thermodynamic calculation has proved that the oxygen potential for carbon deposition is $P\left(\mathrm{O}_{2}\right)=10^{-19}$ $10^{-20}$ atm at $1000^{\circ} \mathrm{C}$. This $P\left(\mathrm{O}_{2}\right)$ range is well close to that of phase transition boundary of ceria. ${ }^{15,16}$ The fluorite $\mathrm{CeO}_{2}$ phase is converted into the $\mathrm{Ce}_{3} \mathrm{O}_{5}$ phase with the rare-earth type-C structure at $P\left(\mathrm{O}_{2}\right)$ $=10^{-18}-10^{-19}$ atm at $1000^{\circ} \mathrm{C}$. Therefore, this $P\left(\mathrm{O}_{2}\right)$-dependent phase transition in ceria will have a significant impact on the difference in the carbon deposition behavior under open-circuit and discharge conditions. As described above, many factors have to be considered to design the anodes with high tolerance to carbon deposition for use in internal reforming operation.

It is commonly recognized that the degradation over anodes induced by carbon deposition is a time-dependent phenomenon; i.e., the microstructural change of nickel particles and blocking of open pore. However, there is no report dealing with the degradation phenomena from the aspect of time scale. Most of reports in this field have evaluated only the transient performance and the presence or absence of carbon deposition in a short time. In this study, we focus on the influence of the materials and cell configuration, especially the anode thickness, on the performance stability during the long-term operation with hydrocarbon fuels. Two cermet anodes of Ni-YSZ and Ni-SDC with different thickness were applied.

\section{Experimental}

Two cermets of Ni-YSZ and Ni-SDC were applied as fuel electrodes. The commercially available NiO-YSZ powder (AGC seimi chemical company) was used for the slurry preparation. 


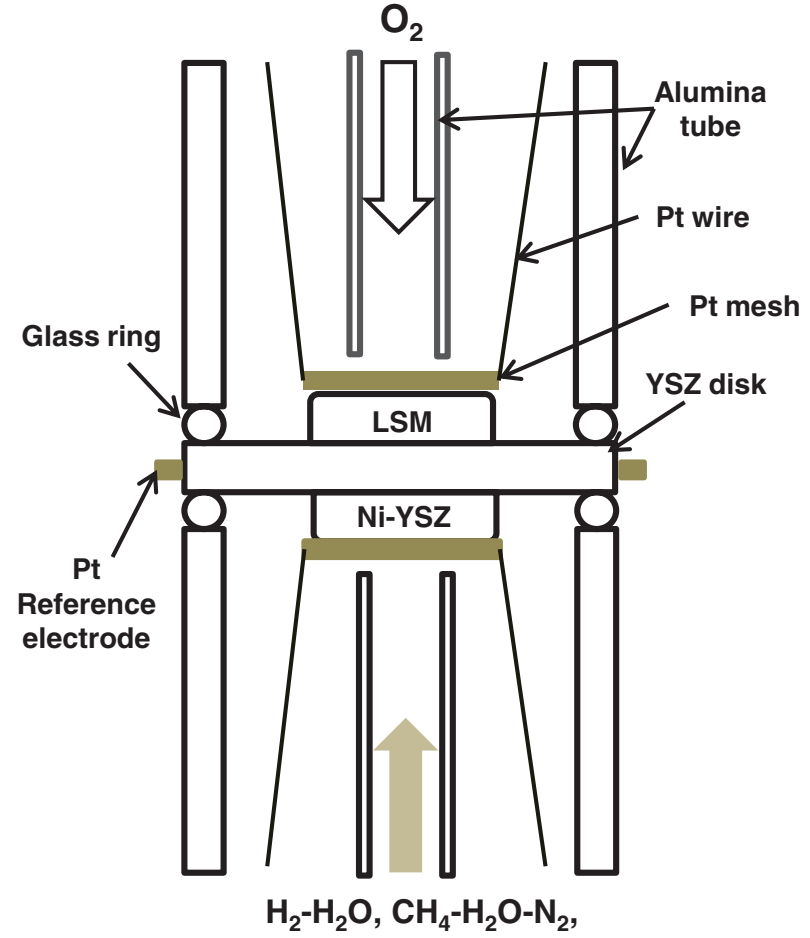

Figure 1 Schematic drawing for the arrangement of testing system.

Samaria-doped ceria with a composition of $\mathrm{Ce}_{0.8} \mathrm{Sm}_{0.9} \mathrm{O}_{1.9}$ (SDC) was prepared by the oxalates precipitation procedure. ${ }^{1}$ The volumetric ratios of $\mathrm{Ni}$ to YSZ and $\mathrm{Ni}$ to SDC in the cermets were fixed to be 47 to 53 and 50 to 50, respectively. A perovskite type oxide of $\left(\mathrm{La}_{0.8} \mathrm{Sr}_{0.2}\right)_{0.97} \mathrm{MnO}_{3}$ (LSM) was applied as an air electrode.

The cells were prepared by applying each paste of the electrode powder onto a YSZ disk (Tosoh, thickness: $500 \mu \mathrm{m}$, diameter: $24 \mathrm{~mm}$ ). The powder of electrode materials was mixed with polyethylene glycol (Wako Pure Chemical Industries) to form slurry. The thickness of anode was controlled to be ca. 10, 20, and $30 \mu \mathrm{m}$ throughout this study. The NiO-YSZ slurry was screen-printed on one face of the YSZ disk at the central part with $6 \mathrm{~mm}$ diameter, followed by the calcination at $1400^{\circ} \mathrm{C}$ for $5 \mathrm{~h}$. In the case of NiO-SDC, the slurry was screen-printed in the same manner as NiO-YSZ, and then the disk was fired at $1280^{\circ} \mathrm{C}$ for $3 \mathrm{~h}$ to avoid the chemical reaction between YSZ and SDC. ${ }^{17,18}$ The air electrode slurry was coated with the same way on the other face of the disk, and subsequently heated at $1150^{\circ} \mathrm{C}$ for $5 \mathrm{~h}$. The fabricated cell was sandwiched by alumina tubes with a Pyrex glass seal, as shown in Fig. 1.

Power generation characteristics of fuel cells were evaluated at $1000^{\circ} \mathrm{C}$. After heating the sample up to the desired temperature, diluted and pure hydrogen were supplied to the fuel electrode for the reduction of $\mathrm{NiO}$. A gaseous mixture of $3 \% \mathrm{H}_{2} \mathrm{O}-97 \% \mathrm{H}_{2}$ or $30 \%$ $\mathrm{CH}_{4}-3 \% \mathrm{H}_{2} \mathrm{O}-67 \% \mathrm{~N}_{2}(\mathrm{~S} / \mathrm{C}=0.1)$ was fed to the anode with a flow rate of $100 \mathrm{~mL} \mathrm{~min}^{-1}$. Note that the carbon deposition occurs spontaneously in $\mathrm{CH}_{4}-\mathrm{H}_{2} \mathrm{O}-\mathrm{N}_{2}$ with an $\mathrm{S} / \mathrm{C}$ ratio of 0.1 at $1000^{\circ} \mathrm{C}$. Oxygen was supplied to the cathode as an oxidant with a flow rate of $100 \mathrm{~mL} \mathrm{~min}^{-1}$. Electrochemical measurements were conducted by the CellTest system (Solartron Analytical, potentiostat/galvanostat $1470 \mathrm{E}$ and frequency response analyzer 1455A). The series of experiments in this study was performed several times and consistent results were obtained.

After power generation, the cross-section of anodes were analyzed by a scanning electron microscope (SEM, NVision 40, Carl Zeiss) equipped with an energy-dispersive X-ray spectrometer (EDX, Oxford). The state of deposited carbon was studied by Raman spectroscopy (Horiba Jobin Yvon, LabRAM HR-800). Raman spectra were recorded by irradiating $\mathrm{Ar}^{+}$laser $(514.5 \mathrm{~nm})$ focused to a $1-\mu \mathrm{m}-$ size spot.

\section{Results and Discussion}

The performance of the cells employing Ni-YSZ anodes of three different thicknesses was examined at $1000^{\circ} \mathrm{C}$ by supplying $3 \% \mathrm{H}_{2} \mathrm{O}$ $97 \% \mathrm{H}_{2}$ and $\mathrm{CH}_{4}-\mathrm{H}_{2} \mathrm{O}-\mathrm{N}_{2}$ mixture $(\mathrm{S} / \mathrm{C}=0.1)$ as fuels. The currentvoltage $(I-V)$ curves are shown in Fig. 2. In the case of humidified hydrogen fuel, OCVs of all cells were identical to the theoretical values derived from the Nernst equation, and $I-V$ characteristics were independent of the anode thickness. In contrast, in a humidified methane $(\mathrm{S} / \mathrm{C}=0.1)$ fuel, OCV and cell performance depended on the anode thickness. The cell with a $30-\mu \mathrm{m}$ thick anode showed the highest OCV of $1.22 \mathrm{~V}$, and OCV decreased with a reduction in the anode thickness. This suggested that the reforming reaction of methane were strongly related with an anode thickness. A lack of exposed nickel surface area would be attributable to the low OCV for $10 \mu \mathrm{m}$ sample in the Ni-YSZ anode. Although such a difference was prominent at low current density, the performances of three different cells converged
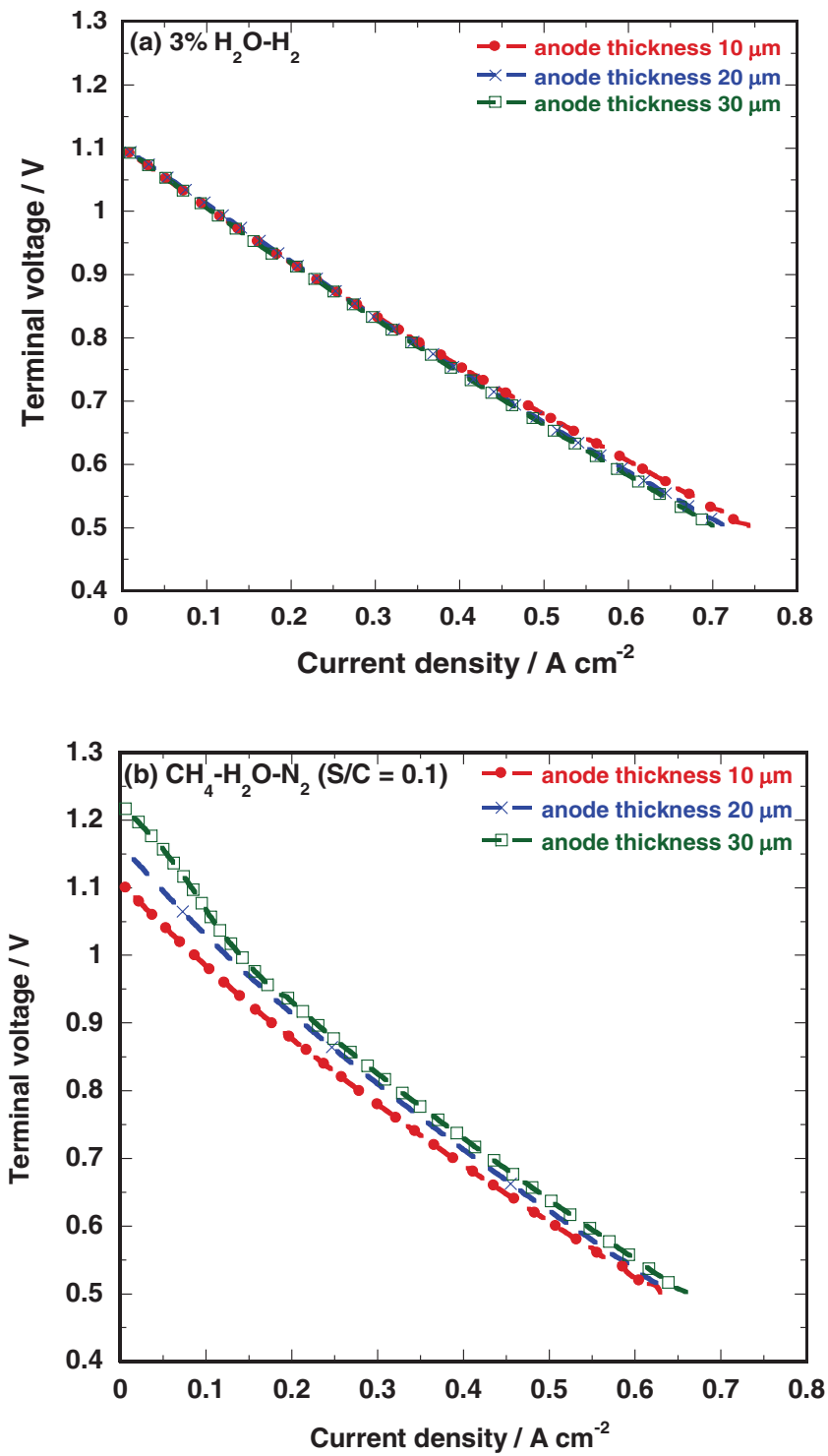

Figure $2 I-V$ curves of single cells employing $\mathrm{Ni}-\mathrm{YSZ}$ anodes with different thicknesses under supply of (a) $3 \% \mathrm{H}_{2} \mathrm{O}-97 \% \mathrm{H}_{2}$ and (b) $\mathrm{CH}_{4}-\mathrm{H}_{2} \mathrm{O}-\mathrm{N}_{2}$ mixture $(\mathrm{S} / \mathrm{C}=0.1)$ at $1000^{\circ} \mathrm{C}$. 

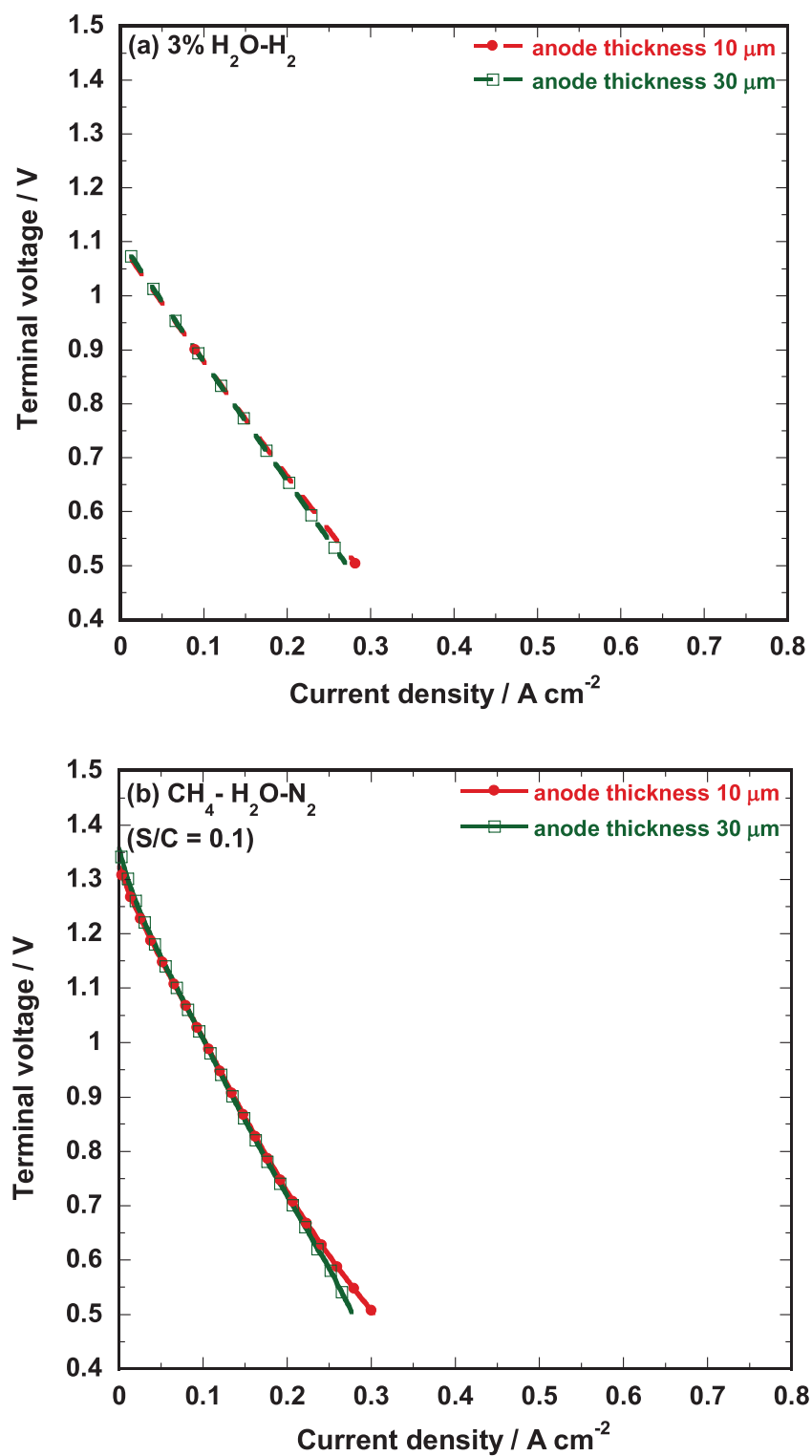

Figure $3 I$ - $V$ curves of single cells employing Ni-SDC anodes with different thicknesses under supply of (a) $3 \% \mathrm{H}_{2} \mathrm{O}-97 \% \mathrm{H}_{2}$ and (b) $\mathrm{CH}_{4}-\mathrm{H}_{2} \mathrm{O}-\mathrm{N}_{2}$ mixture $(\mathrm{S} / \mathrm{C}=0.1)$ at $1000^{\circ} \mathrm{C}$

into the same level at high current density of ca. $0.6 \mathrm{~A} \mathrm{~cm}^{-2}$. This is because the steam generated by the discharge operation promoted the reforming reaction even in thin anode layer.

The same experiments were conducted for the cells employing $\mathrm{Ni}-$ SDC anodes, and results were depicted in Fig. 3. The cells of different anode thickness showed a comparable performance and theoretical OCV in humidified hydrogen, though the current density achieved at $0.5 \mathrm{~V}$ was about half of that obtained for Ni-YSZ anode. This low performance is mainly due to the low firing temperature of Ni-SDC on the electrolyte, which is related to the weak adhesion between each oxide component. Note that in a humidified methane fuel, a distinct difference was observed between Ni-SDC and Ni-YSZ: The cell performance and $\mathrm{OCV}$ were independent of the thickness of $\mathrm{Ni}-$ SDC anode. $P\left(\mathrm{O}_{2}\right)$ in the anode compartment can be estimated to be ca. $10^{-22} \mathrm{~atm}$ from the obtained OCV of $1.35 \mathrm{~V}$, which is within the carbon deposition region in the $\mathrm{C}-\mathrm{H}-\mathrm{O}$ ternary diagram. ${ }^{9}$ Thus, the thermal cracking of methane occurs spontaneously. Considering that $\mathrm{Ni}-\mathrm{SDC}$ provided the higher OCV as compared with $\mathrm{Ni}-\mathrm{YSZ}, \mathrm{SDC}$ should promote the cracking reaction. This result is consistent with
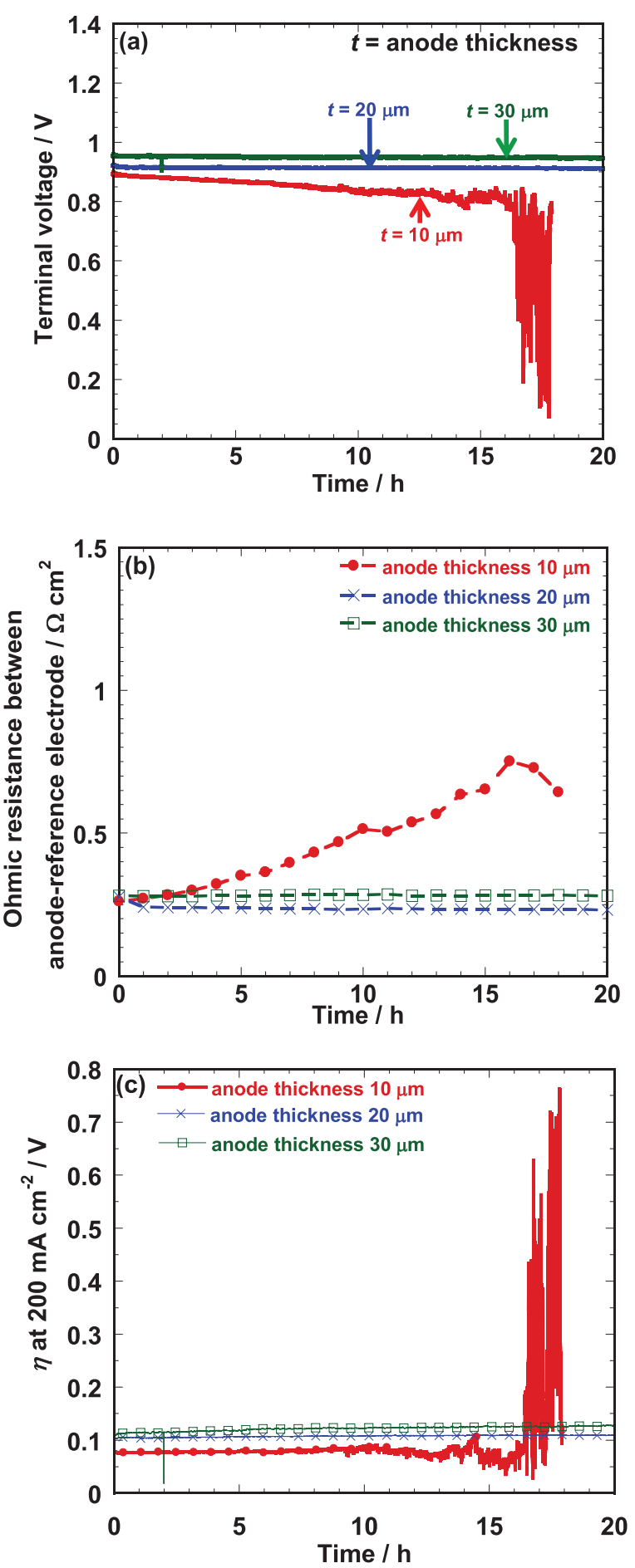

Figure 4 Time courses of (a) terminal voltage, (b) ohmic resistance between anode and reference electrode, and (c) anodic overpotential with Ni-YSZ anodes at a constant current density of $0.2 \mathrm{~A} \mathrm{~cm}^{-2}$ with a supply of $\mathrm{CH}_{4}$ $\mathrm{H}_{2} \mathrm{O}-\mathrm{N}_{2}$ mixture $(\mathrm{S} / \mathrm{C}=0.1)$ at $1000^{\circ} \mathrm{C}$.

that reported by Iida et al.; ${ }^{1}$ carbon tends to deposit over Ni-SDC anodes than over Ni-YSZ anode at the open-circuit state.

Time course of terminal voltage measured at a constant current density of $0.2 \mathrm{~A} \mathrm{~cm}^{-2}$ with a supply of $\mathrm{CH}_{4}-\mathrm{H}_{2} \mathrm{O}-\mathrm{N}_{2}$ mixture $(\mathrm{S} / \mathrm{C}$ $=0.1$ ) for $\mathrm{Ni}-\mathrm{YSZ}$ is shown in Fig. 4a. Corresponding changes in ohmic resistance between anode and reference electrode and the anode overpotential during discharge are also depicted in Figs. $4 \mathrm{~b}$ and $4 \mathrm{c}$, respectively. The initial performance was enhanced with increasing anode thickness. The cells with 20 - and $30-\mu \mathrm{m}$ thick anodes exhibited 
stable performance for $20 \mathrm{~h}$. In response to this behavior, no changes in the ohmic resistance and the overpotential were confirmed. Moreover, in the case of cell with $30-\mu \mathrm{m}$ thick anode, the terminal voltage was only slightly reduced for $106 \mathrm{~h}$ due to an increase in overpotential. On the other hand, the gradual decrease and subsequent oscillation in the terminal voltage were observed for $10-\mu \mathrm{m}$ thick anode. Since the test condition in the present study was set within the carbon deposition region expected from the thermodynamic equilibrium, the performance deterioration observed in the $10-\mu \mathrm{m}$ thick anode will be caused by the carbon deposition. The ohmic resistance of the $10-\mu \mathrm{m}$ thick anode continuously increased with an elapse of time, while the anode overpotential kept stable within ca. $10 \mathrm{~h}$. The carbon deposition generally proceeds from the surface of the anode to the electrode/electrolyte interface. It has been assumed that the coke buildup should induce the volume expansion of Ni particles and micro-cracking between YSZ and $\mathrm{Ni}$, presumably leading to an interruption of anode current collection pathways. ${ }^{10}$ Thus, the deposited carbon mainly damaged the electric conduction path in the upper layer of anode at the initial stage of degradation. With an elapsed time of 10-16 h, the slight oscillation in anodic overpotential was observed. Then, the overpotential steeply increased and oscillated with amplitude of ca. $0.6 \mathrm{~V}$. Thus, it can be expected that the accumulated carbon disturbed the gas diffusion in the anode. As a result, the variation in hydrogen concentration at the triple phase boundary (TPB) would give rise to this oscillatory behavior of the anode overpotential. Similar degradation for the thin anode layer could be observed reproducibly: the performance of cell with $7-\mu \mathrm{m}$ thick anode was suddenly deteriorated in $5 \mathrm{~h}$. The same series of measurements were conducted for the cells with Ni-SDC anodes, and results are summarized in Fig. 5. The cell performance was improved obviously during discharge at $0.2 \mathrm{~A} \mathrm{~cm}^{-2}$ for $20 \mathrm{~h}$ regardless of anode thickness. Concomitant reductions in ohmic resistance and overpotential were observed. These improvements upon discharge are related to the expansion of electrochemical active area as well as an increase in electronic conductivity of SDC, which is induced by partial reduction of $\mathrm{Ce}^{4+}$ to $\mathrm{Ce}^{3+}$ under reducing atmospheres. ${ }^{19-22}$ In addition, catalytic $\mathrm{CH}_{4}$ decomposition and reactions of reformed gases were examined on stripe-shaped $\mathrm{Ni}$ on the YSZ and YDC with secondary ion mass spectrometry (SIMS) by Horita et al. ${ }^{23}$ According to results of YDC substrate, it has been indicated that water vapor adsorbs on the Ni surface and dissociates into hydrogen $(\mathrm{H})$. The resultant hydrogen (H) transfers to the Ni/YDC interface. Subsequently the charge transfer between $\mathrm{H}$ and $\mathrm{Ce}^{4+}$ occurs, leading to the formation of proton in YDC. The protons can react with $\mathrm{O}^{2-}$ to form $\mathrm{H}_{2} \mathrm{O}$, which evaporates from the surface of YDC. This series of reaction process may enhance the concentrations of water on the Ni surface. The similar phenomenon can be considered to occur in the Ni-SDC anode. Thus, the methane reforming reaction may promote in the Ni-SDC anode to improve cell performance.

Microstructural observation and Raman spectroscopy were conducted for the anodes operated in Figs. 4 and 5 to correlate the electrochemical behavior and the state of deposited carbon in the anode layer. The typical backscattered electron (BSE) images of the whole $\mathrm{Ni}-\mathrm{YSZ}$ and Ni-SDC anodes are shown in Fig. 6. The light gray parts correspond to the $\mathrm{Ni}$, YSZ, or SDC particles, whereas the dark gray parts were assigned to carbon by EDX analysis. For the $10 \mu \mathrm{m}$-thick $\mathrm{Ni}-\mathrm{YSZ}$ anode, a large amount of carbon obstructed the pores in the whole anode layer. In contrast, carbon was observed only in the vicinity of surface for the $30-\mu \mathrm{m}$ thick Ni-YSZ. As to the thick electrode, we expected that the top surface could "buffer" the electrochemical reaction sites at the interface from carbon deposition. Furthermore, because most of Ni particles remained uncovered, the methane reforming reaction and the removal of carbon by the generated $\mathrm{H}_{2} \mathrm{O}$ and $\mathrm{CO}_{2}$ would readily proceed. In addition, after power generation for $106 \mathrm{~h}$, carbon was observed obviously in the vicinity of surface and deposited scarcely near the electrolyte/anode interface. In the case of $30-\mu \mathrm{m}$ thick Ni-SDC anode, formation of carbon was confirmed only in the vicinity of surface. Note that in the $10-\mu \mathrm{m}$ thick anode, a small amount of carbon was observed. This high resistivity to the carbon deposition for Ni-SDC will result from the expansion of electrochem-
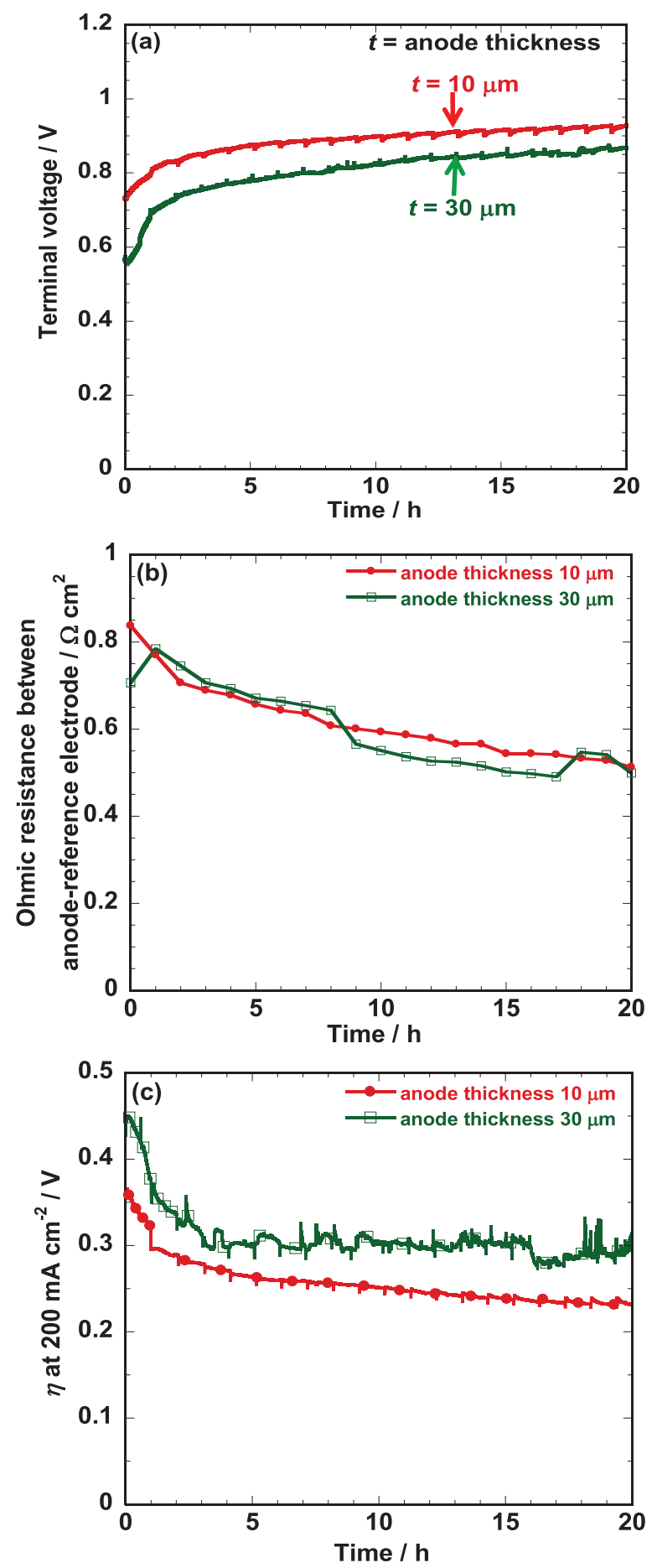

Figure 5 Time courses of (a) terminal voltage, (b) ohmic resistance between anode and reference electrode, and (c) anodic overpotential with Ni-SDC anodes at a constant current density of $0.2 \mathrm{~A} \mathrm{~cm}^{-2}$ with a supply of $\mathrm{CH}_{4}$ $\mathrm{H}_{2} \mathrm{O}-\mathrm{N}_{2}$ mixture $(\mathrm{S} / \mathrm{C}=0.1)$ at $1000^{\circ} \mathrm{C}$.

ical active area as well as an increment in number of reaction sites. The former is related to the inherent chemical properties of ceria such as high solubility of proton, surface catalytic activity, and surface oxygen exchange etc., and the latter is ascribable to the partial reduction of ceria as mentioned above, which provides the additional electronic conduction path. ${ }^{22}$

Figure 7 shows Raman spectra measured along the anode thickness direction, from the anode/electrolyte interface to the surface. The band at $1585 \mathrm{~cm}^{-1}$ arises from the highly ordered graphite, which is 

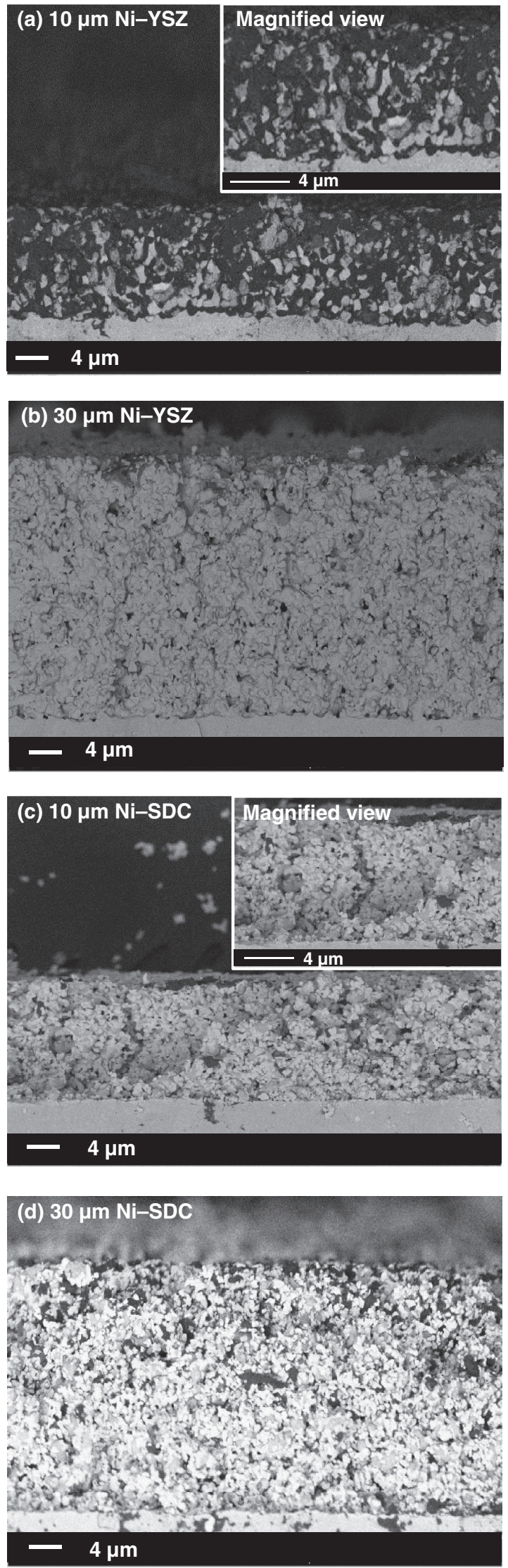

Figure 6 Backscattered electron images of the whole (a, b) Ni-YSZ and (c, d) Ni-SDC anode layer in (a, c) 10- $\mu \mathrm{m}$ and (b, d) 30- $\mu \mathrm{m}$ thicknesses after the discharge at $0.2 \mathrm{~A} \mathrm{~cm}^{-2}$ with a supply of $\mathrm{CH}_{4}-\mathrm{H}_{2} \mathrm{O}-\mathrm{N}_{2}$ mixture $(\mathrm{S} / \mathrm{C}=0.1)$ at $1000^{\circ} \mathrm{C}$.
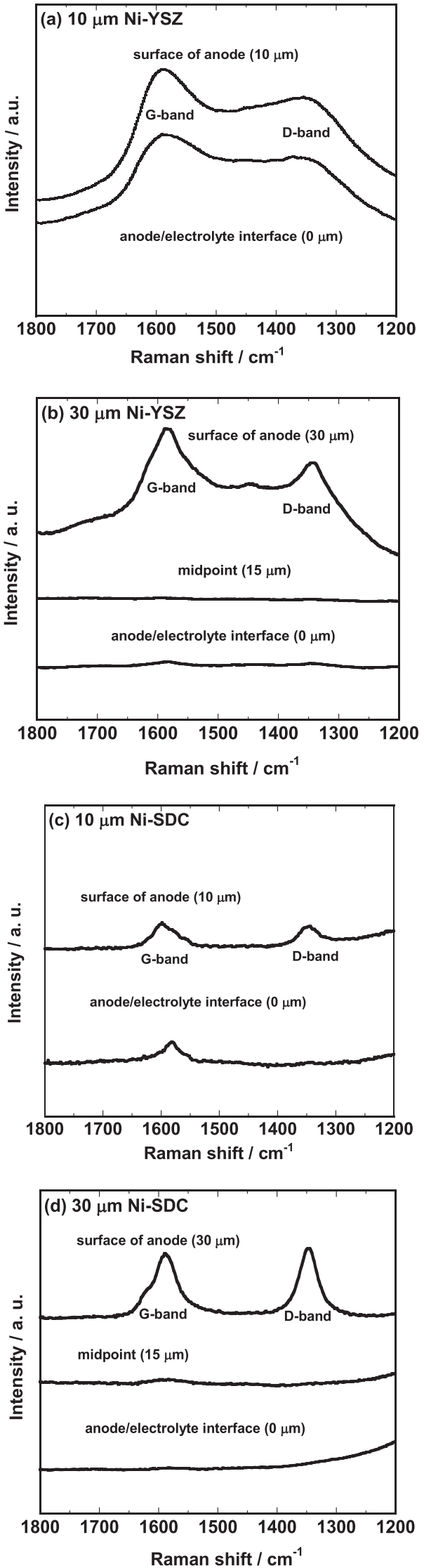

Figure 7 Raman spectra of anode along the electrode thickness direction for (a) $10-\mu \mathrm{m}$ and (b) $30-\mu \mathrm{m}$ thick Ni-YSZ, and (c) $10-\mu \mathrm{m}$ and (d) $30-\mu \mathrm{m}$ thick $\mathrm{Ni}-\mathrm{SDC}$ after discharge at $0.2 \mathrm{~A} \mathrm{~cm}^{-2}$ with a supply of $\mathrm{CH}_{4}-\mathrm{H}_{2} \mathrm{O}-\mathrm{N}_{2}$ mixture $(\mathrm{S} / \mathrm{C}=0.1)$ at $1000^{\circ} \mathrm{C}$. 
generally labeled as "G". The band at $1350 \mathrm{~cm}^{-1}$, labeled as "D", is attributed to disordered graphite carbon. ${ }^{24-26}$ The spectra of $10-\mu \mathrm{m}$ thick Ni-YSZ exhibited two broad peaks with low resolution, ascribable to G- and D-bands, regardless of position in the anode layer. Such a characteristic spectrum indicates the formation of amorphous carbon. ${ }^{27}$ Note that this type of carbonaceous species has relatively low electric conductivity; $;^{27-29}$ the electric conductivity of the graphite at room temperature is ca. 100-fold higher than that of amorphous carbon. ${ }^{30}$ Therefore, the formation of low conductive carbon resulted in an increase in ohmic resistance between anode and reference electrode during galvanostatic operation as observed in Fig. 4b. On the other hand, considering the analogous spectra observed in the vicinity of surface for $30-\mu \mathrm{m}$ thick anode, the low conductive carbon was formed only at the surface. Moreover, the deposited carbon was scarcely detected at the interface with the electrolyte as was observed in the BSE image (see Fig. 6b). Thus, the stable power generation was achieved without any changes in electrochemical parameters (see Fig. 4). The results for the $20 \mu \mathrm{m}$ sample were analogous to those for the $30 \mu \mathrm{m}$ sample from the microstructural observation and Raman analysis. In the case of Ni-SDC, spectrum shapes of deposited carbon were different from those in Ni-YSZ. This means that the chemical state of deposited carbon depends on the oxide component in the cermet. Sumi et al. also reported that the different characteristics of the carbon were observed in the Ni-YSZ and Ni-ScSZ anode by Raman spectroscopy. ${ }^{2}$ Since the peaks of D- and G-bands were separated clearly, the deposited carbon in Ni-SDC leads to higher electric conductivity as compared with that in Ni-YSZ. This will contribute to reductions in ohmic resistance and overpotential, as well as the appearance of electronic conduction in SDC as observed in Fig. 5.

It is striking that in this study, the amorphous carbon with low conductivity was formed over Ni-YSZ anode. Such a characteristic carbon has not been observed over Ni-YSZ during discharge at 0.3 $\mathrm{A} \mathrm{cm}-2$ for $20 \mathrm{~h}$ with feeding a methane fuel with S/C of 0.5 at $1000^{\circ} \mathrm{C}$; Raman spectra were analogous to those for Ni-SDC. ${ }^{2}$ This indicates that the discharge conditions strongly affect the deposited amount, crystallinity and electric conductivity of carbon even over same electrode material. Because the negative effect induced by such carbonaceous species will be prominent upon the long-term operation, the operating conditions and constituent materials have to be considered carefully to avoid the carbon deposition.

\section{Conclusions}

The influence of the anode material thicknesses on the performance stability under a humidified methane $(\mathrm{S} / \mathrm{C}=0.1)$ at $1000^{\circ} \mathrm{C}$ was studied. The cell with Ni-SDC anode showed gradual improvement in performance during discharge regardless of anode thickness. The NiSDC anode will suppress the carbon deposition effectively and the performance was improved obviously during discharge. These improvements upon discharge were related to the expansion of electrochemical active area as well as an increase in electronic conductivity of SDC. The stable performance appeared in $30 \mu \mathrm{m}$-thick Ni-YSZ anodes because the top surface of Ni-YSZ anode served as the buffer layer to suppress the damage in reaction sites near the anode/electrolyte interface and support the effective removal of deposited carbon by the steam electrochemically-generated. However, the deterioration in performance was observed with $10 \mu \mathrm{m}$-thick Ni-YSZ anode within $18 \mathrm{~h}$. For this anode, a large amount of amorphous carbon obstructed the pores in the whole anode layer. This carbonaceous species possess relatively low electric conductivity than that deposited in Ni-SDC. Accordingly, the cell performance was related to the deposited area and carbonaceous species, which was determined by the operating conditions and constituent materials. It is concluded from the present investigation that an appropriate combination of fuel electrode material, and cell configuration should be taken into consideration for stable operation in the internal reforming of SOFCs.

\section{Acknowledgment}

This work was partially supported by New Energy and Industrial Technology Development Organization (NEDO), Japan (Development of System and Elemental Technology on Solid Oxide Fuel Cell) and Core Research for Evolutional Science and Technology (CREST) of Japan Science and Technology Agency (JST).

\section{References}

1. T. Iida, M. Kawano, T. Matsui, R. Kikuchi, and K. Eguchi, J. Electrochem. Soc., 154, B234 (2007).

2. H. Sumi, Y. Lee, H. Muroyama, T Matsui, and K. Eguchi, J. Electrochem. Soc., 157, B1118 (2010)

3. J.-H. Koh, Y.-S. Yoo, J.-W. Park, and H. C. Lim, Solid State Ionics, 149, 157 (2002).

4. A. Weber, B. Sauer, A. C. Müller, D. Herbstritt, and E. Ivers-Tiffée, Solid State Ionics, 152-153, 543 (2002).

5. T. Kim, G. Liu, M. Boaro, S.-I. Lee, J. M. Vohs, R. J. Gorte, O. H. Al-Madhi, and B. O. Dabbousi, J. Power Sources, 155, 231 (2006).

6. T. Matsui, R. Kishida, J. Kim, H. Muroyama, and K. Eguchi, J. Electrochem. Soc., 157, B776 (2010).

7. T. Takeguchi, Y. Kani, T. Yano, R. Kikuchi, K. Eguchi, K. Tsujimoto, Y. Uchida, A. Ueno, K. Omoshiki, and M. Aizawa, J. Power Sources, 112, 588 (2002).

8. A. Abudula, M. Ihara, H. Komiyama, and K. Yamada, Solid State Ionics, 86-88, 1203 (1996).

9. K. Eguchi, H. Kojo, T. Takeguchi, R. Kikuchi, and K. Sasaki, Solid State Ionics, 152-153, 411 (2002).

10. Y. Lin, Z. Zhan, J. Liu, and S. A. Barnett, Solid State Ionics, 176, 1827 (2005).

11. K. Otsuka, Y. Wang, E. Sunada, and I. Yamanaka, J. Catalysis, 175, 152 (1998).

12. T. Zhu and M. Flytzani-Stephanopoulos, Appl. Catal. A: General, 208, 403 (2001).

13. E. S. Putna, J. Stubenrauch, J. M. Vohs, and R. J. Gorte, Langmuir, 11, 4832 (1995).

14. K. T. Lee, C. M. Gore, and E. D. Wachsman, J. Mater. Chem., 22, 22405 (2012).

15. K. Kitayama, K. Nojiri, T. Sugihara, and T. Katsura, J. Solid State Chem., 56, 1 (1985).

16. M. Zinkevich, D. Djurovic, and F. Aldinger, Solid State Ionics, 177, 989 (2006).

17. A. Tsoga, A. Gupta, A Naoumidis, and P. Nikolopoulos, Acta. Mater, 48, 4709 (2000).

18. X.-D. Zhou, B. Scarfino, and H. U. Anderson, Solid State Ionics, 175, 19 (2004).

19. H. L Tuller and A. S Nowick, J. Electrochem. Soc., 122, 255 (1975).

20. H. Yahiro, K. Eguchi, and H. Arai, Solid State Ionics, 36, 71 (1989).

21. M. Godickemeier and L. J. Gaucker, J. Electrochem. Soc., 145, 414 (1998).

22. H. Yokokawa, T. Horita, N. Sasaki, K. Yamaji, M. E. Brito, Y.-P. Xiong, and H. Kishimoto, Solid State Ionics, 174, 205 (2004).

23. T. Horita, K. Yamaji, T. Kato, N. Sasaki, and H. Yokokawa, J. Power sources, 131, 299 (2004).

24. M. B. Pomfret, J. Marda, G. S. Jackson, B. W. Eichhorn, A. M. Dean, and R. A. Walker, J. Phys. Chem. C., 112, 5232 (2008).

25. K. Yamaji, H. Kishimoto, Y. Xiong, T. Horita, N. Sasaki, M. E. Brito, and H. Yokokawa, Solid State Ionics, 179, 1596 (2008).

26. K. Yashiro, M. Takase, K. Sato, T. Kawada, and J. Mizusaki, ECS Trans., 16, 213 (2008).

27. M. Koós, S. H. S. Moustafa, E. Szilágyi, and I. Pócsik, Diam. Relat. Mater., 8, 1919 (1999).

28. M. Weiler, S. Sattel, T. Giessen, K. Jung, H. Ehrhardt, V. S. Veerasamy, and J. Robertson, Phys. Rev. B, 53, 1594 (1996).

29. E. G. Gerstner, P. B. Lukins, D. R. Mckenzie, and D. G. McCulloch, Phys. Rev. B, 54, 14504 (1996).

30. S. Stankovich, D. A. Dikin, R. D. Piner, K. A. Kohlhaas, A. Kleinhammes, Y. Jia, Y. Wu, S. T. Nguyen, and R. S. Ruoff, Carbon, 45, 1558 (2007). 